\title{
Psychodynamic Study about Reflux and Colic During the First Year of Life
}

\author{
Deborah Juliana dos Santos Zacara $^{1}$ \\ Izabella Paiva Monteiro de Barros ${ }^{2}$
}

\begin{abstract}
The aim of this study was to analyze the psychodynamics of three mother-infant pairs with reflux diagnosis and two with colic diagnosis and their possible relation to the referred psychosomatic disorders. Qualitative exploratory study in which the sample was composed after signing the informed consent form. Instruments: semi-directed interview, seven boards of the Thematic Apperception Test and Naturalistic Observation. Content analysis of the interviews and TAT boards was performed and the way the mother perceived the productions of the baby was considered from naturalistic observation. These analyses supported psychodynamic interpretations of the functioning of the dyads studied. As main results, the reflux group highlights the need for maternal support and the presence of maternal ambivalence. In mother-infant pairs with colic, there is anxiety regarding their own ability to care for their child. In both groups, there is environmental influence on the way mothers feel about sufficiently good mothering.
\end{abstract}

Keywords: motherhood, colic in the first three months of life, psychosomatic disorder, mind body relations, gastrointestinal system

\section{Estudo Psicodinâmico dos Sintomas Refluxo e Cólica no Primeiro Ano de Vida}

Resumo: O objetivo deste estudo foi analisar a psicodinâmica de três pares mãe-bebê com diagnóstico de refluxo e dois com diagnóstico de cólica e sua possível relação com as referidas desordens psicossomáticas. Trata-se de estudo qualitativo e exploratório cuja a amostra foi composta após assinatura do termo de consentimento. Instrumentos: entrevista semi-dirigida, sete pranchas do Teste de Apercepção Temática (TAT) e Observação Naturalista. Procedeu-se análise de conteúdo das entrevistas e das pranchas do TAT e, da observação naturalista, valorizou-se principalmente a maneira como a mãe percebeu as produções do bebê. Estas análises respaldaram interpretações psicodinâmicas do funcionamento das díades estudadas. Como principais resultados, destaca-se no grupo refluxo a necessidade de apoio para maternar e presença de ambivalência materna. Já nos pares mães-bebês com cólica, há ansiedade frente à própria capacidade de cuidar do filho. Nos dois grupos, há influência ambiental na maneira como as mães se sentem no exercício da maternagem suficientemente boa.

Palavras-chave: maternidade, cólica do primeiro trimestre, desorganização psicossomática, relações mente-corpo, sistema gastrointestinal

\section{Estudio Psicodinámico de los Síntomas de Reflujo y Cólico en el Primer Año de Vida}

Resumen: El objetivo de este estudio fue analizar la psicodinámica de 3 parejas madre-bebé con diagnóstico de reflujo y 2 con cólico y la posible relación de estos síntomas con trastornos psicosomáticos. El estudio es cualitativo y exploratorio. La muestra se compuso después de que los participantes firmaron el formulario de consentimiento. Instrumentos: entrevista semidirigida, 7 láminas del Test de Apercepción Temática y observación naturalista. Se realizó un análisis de contenido de las entrevistas y de las láminas del TAT y, a partir de la observación naturalista, se valoró la forma en que la madre percibió las producciones del bebé. Estos análisis respaldaron interpretaciones psicodinámicas del funcionamiento de las díadas estudiadas. Como resultados principales, en el grupo reflujo se destacan la necesidad de apoyo a la madre y la presencia de ambivalencia materna. En las parejas madre-bebé con cólico, se percibe ansiedad con respecto a la capacidad para cuidar al niño. En ambos grupos, hubo influencia ambiental en los sentimientos de las madres sobre el buen ejercicio de la maternidad.

Palabras clave: maternidad, cólico del primer trimestre, desorganización psicosomática, relaciones mente cuerpo, sistema gastrointestinal

\section{${ }^{1}$ Universidade Presbiteriana Mackenzie, São Paulo-SP, Brazil \\ ${ }^{2}$ Universidade Federal do Pará, Belém-PA, Brazil}

Article derived from a graduation study conducted by the first author, under the supervision of the second author, in the course of Psychology at the Center for Biological and Health Sciences at Universidade Presbiteriana Mackenzie in 2007.

Correspondence address: Izabella Paiva Monteiro de Barros. Universidade Federal do Pará. Rua Augusto Corrêa, 01, campus universitário do Guamá. Belém-PA, Brazil. CEP 66.075-110. E-mail: barrosizabella23@gmail.com
Throughout the processes of constitution of the psychic subject, one must take into account the infant and the adult caring for it - the incarnate primordial agent, who is usually the mother - as many difficulties of the young child are associated with the type of relationship established in the mother-infant dyad (Edelstein, 2000). According to the literature, infantile colic and gastroesophageal reflux (GER) are phenomena that may eventually occur in the child's 
early years as an effect of the type of relationship with the mother, and are also known as psychofunctional symptoms (Edelstein, 2000; Scalco \& Donelli, 2014). Thus, the meaning of the child's psychosomatic disorders can be found in the maternity structure (Ranña, 2015).

The psychodynamic study of reflux and colic symptoms in the first year of life, which is the object of discussion in this article, regarding social relevance, can add value considering that in view of the results found, it was possible to use information in both clinical practice, as in educational contexts to instrumentalize parents and caregivers of young children.

From the scientific point of view, the importance of the study is confirmed considering there is a shortage of literature in the area and, thus, an empirical and qualitative study in Psychology is considered of great importance as a way of contributing to the advancement in the Humanities and Social Sciences.

For the psychological sciences, the theme is equally relevant since colic and reflux often result from intrinsic aspects of the mother-infant relationship. If the pregnant and/ or postpartum women have the opportunity to be listened such symptoms can be analyzed, discussed and treated by Psychology in a preventive manner.

In order to establish a clearer relationship from the theoretical-clinical point of view, we sought the contribution of not only classic but also current studies in the child development area, such as Edelstein (2000), Ranña (2015) and Winnicott (1958/2000), who point out that the mother's gaze is fundamental in the constitution of the infant as a subject. Thus, psychoanalytic science emphasizes the importance of primary mothering and the environment, not only as facilitators, but also as a source of possible barriers to individual formation. Freudian constructs were responsible for the idea that the foundations for an individual's mental health, as well as for the formation of the Self, are sustained in early childhood by the mother (Winnicott, 1958/2000).

The fundamental tasks of sufficiently good motherhood in the infant's first year of life, as described by Winnicott (1958/2000), are providing that the small child gradually encounter shared reality and be able to elaborate affective life experiences and drive requirements in their own psychic apparatus.

The importance of breastfeeding stands out in the first year of life, prime time for both psychic constitution and major developmental acquisitions. Vendruscolo, Bolzan, Crestani, Souza \& Moraes (2012) focus on the theme of breastfeeding and infant feeding from a relational aspect, as well as the nutritional and instrumental records, since the introduction or withdrawal of any type of diet are linked to eating times inherent in the mother-infant relationship.

From the maternal referential, the role changes after the birth of a baby are highlighted on the researches by Scalco \& Donelli (2014) that draw attention to the moment in which, when becoming a mother, the woman perceives herself with a reflective task about the need to occupy several places simultaneously. To this end, she recalls her role as daughter to assimilate the one of a mother, a process that will reflect on the quality of maternal care directed to her child. As Pincus \& Dare (1981) point out: "parents, individually and as a couple, must feel sufficiently secure, as well as be able to recognize their confused feelings about the new demands that await them" (p. 51).

Faced with the complex task of caring for a baby, when the mother allows more participation of the father, the isolation will be less frequent and the family satisfaction, greater. The mother thus plays an important role regarding the demand for a more involved father, creating more favorable conditions for the quality/functionality of family life, as Rapoport \& Piccinini (2011) point out: "the possibility of the mother having people assisting her in this new phase and especially in difficult times makes her more available emotionally and physically to adequately meet the child's demands" (p. 215).

As part of the features that characterize good enough mothering, this mother must develop what Winnicott (1958/2000) defined as holding, that is, holding the baby on her lap in a way not devoid of affection, because according to this author, babies are very sensitive to the way they are held. Thus, maternal care goes beyond satisfying the baby's physiological needs. It is not just any holding, but a holding marked by a particular and desiring interest that makes the mother adjust the pressure of her arms to the baby's needs.

Importantly, the existence of contradictory feelings about the baby and motherhood is common because, when conceiving a child there is an important transformation in the woman's life, being the baby a workload and a positive embarrassment, if desired. These transformations occur gradually in both the mother's feelings and body: "If a young woman has not yet begun to want the baby she carries within, she cannot help feeling unhappy" (Winnicott, 1965/1982, p. 19).

According to Winnicott (1958/2000), these flaws and mismatches can be expressed in the disjunction between psyche and soma and cause damage to the infant's psyche on the one hand, and failures in the drive inscription process on the other hand, which according to the psychoanalytic psychosomatic analysis, occurs in the emergence of psychosomatic phenomena (Ranña, 2015). As for these early moments, psychoanalysis as a field of study and intervention can help with its fundamental instruments: listening and early intervention work.

It is worth noting that the mother-infant relationship involves both the baby's somatic functioning (sleep, feeding, bowel movement, motor acquisition) as well as the mother's personal and family life history with her affective and emotional experiences, conflicts and peculiar defense mechanisms (Edelstein, 2000).

In this context of deep connection, the infant's psychic apparatus develops from an undifferentiated initial state, going through successive psychological processes that "emerge from the physiological prototypes and the intersubjective encounter of the relationship with their caregivers, highlighting the importance of the parents' psyche in the process of constitution of the new infant subject” (Ranña, 2015, p. 109). 
It will be the primary maternity that, once operative, will function as a excitement stop of a representational void left by the child's physical and psychic urgencies, providing through language and assumption of a subject in the child a meaning assignment to the child's demands. For example, there will be a reduction in the intensity of colics in the first trimester when the social smile appears, which seems to occur as a result of the excitement stop of instinctual urgencies, when these are contained by the support of maternal representations (Ranña, 2015).

Based on these assumptions, it is possible to say that the infant is characterized as a psychosomatic unity par excellence, given by their own human condition and, therefore, according to Ranña (2015) presents the structural situation (from the point of view of psychic immaturity) more vulnerable to somatization. From the moment that subjective constitution occurs, there is a decrease in somatic manifestations, that is, emotional discharges through the body, because emotional contents are metabolized by their own psychic apparatus (Edelstein, 2000; Scalco \& Donelli, 2014).

According to Rapoport \& Piccinini (2006), social support, especially from the father, influences the mother's well-being and facilitates responsive mothering, especially in stressful times, promoting "the development of a secure infant-mother attachment, in addition to directly affecting the child through contact with the members of this support network" (p. 85).

Barros \& Herzberg (2012) and Scalco \& Donelli (2014), point out that the disturbances of these mother-infant interactions often trigger one of the initial signs of difficulties, both in the developmental record and in the psychic constitution to be installed in the baby. They also emphasize that, exposed to environmental demands, the infant responds through the body psychofunctional symptoms, given that the primordial bond is not providing sufficient psychic support at a time when the child has not yet acquired the capacity for symbolization. Thus, the consequence for these babies is a state of constant emotional restlessness.

According to Scalco \& Donelli (2014) it is a symptom "to be seen", unlike the adult who has the resources to express their feelings through attitudes and words. "Thus, it is supposed that marital adjustment can affect the relationship with the infant, producing somatic manifestations that serve as a denunciation of the mismatch between parents and child" (Peruchi, Donelli, \& Marin, 2016, p. 56).

Infant colic symptoms, for example, have been a well known topic to pediatricians for over a century. The episode of colic in the literature is characterized by a loud, sudden and continuous crying at certain times that do not stop despite various consolation attempts, which can lead parents to exhaustion, loss of patience, frustration, discontinuation of breastfeeding, several visits to the pediatrician, feelings of anxiety, irritation, insecurity and even postpartum depression (Oba \& Falcão, 2014). Studies such as Cristoffel, Silva, Silva, Ferreira \& Macedo (2013) emphasize the emotional origin of this symptom as being more common than gastrointestinal.

Thus, it is relevant to emphasize, according to Saavedra et al. (2003), the need to deepen the knowledge about maternal temperament and the care provided to the infant, since in the literature the definition of the mother of the child with colics is "a depressed, tired woman, with few positive responses when taking care of the child, and inadequate maternal care, and these characteristics could make breastfeeding difficult" (p. 121).

Regarding gastroesophageal reflux (GER) in healthy children under 2 years, regurgitation is the characteristic symptom and should be distinguished from gastroesophageal reflux disease (GERD) (Costa, Silva, Gouveia, \& Pereira Filho, 2004).

According to Costa et al. (2004), episodes of regurgitation in the first two quarters of life may be due to early weaning and/or introduction of food, as the amount of food is given by the caregiver and may not always correspond to the child's "will". Both the intervals between meals and the way the caregiver handles the child after feeding can contribute to gastroesophageal reflux.

In addition, Puccini \& Berretin-Felix (2015) point out that the circumstances of vomiting, choking and shortness of breath, may cause the child to relate eating to discomfort, pain, and displeasure. Therefore, when mothers are oriented, the discomforts related to gastroesophageal reflux often reduce considerably, and this listening and guidance provide parents with greater peace of mind as they help to solve possible doubts (Ravanelli, Côrtes, \& Valentim, 2012).

The research paper entitled "Psychodynamic study of reflux and colic symptoms in the first year of life", which is presented in this article, aimed to deepen the knowledge about the psychodynamic aspects of 3 mother-infant pairs diagnosed with reflux and 2 with diagnosis of colic, in order to establish possible relations with the referred psychosomatic disorganization presented by the infant. In addition, specific objectives of this study were the discussion of the psychosomatic functioning of reflux and colic in the infant and identification of the repercussions on the motherinfant dyad, the comparison of the dynamics of the motherinfant pairs with colic and that of the mother-infant pairs with reflux, as well as the contribution with the clinical use of the Thematic Apperception Test (TAT) in researches.

\section{Method}

\section{Participants}

As this is an exploratory qualitative survey and, considering that in a qualitative search the criterion for defining a sample is not numerical, but a deepening and comprehension of the group to be surveyed, the sample was composed by convenience. This type of sampling occurs when participation is voluntary and/or when sample elements are chosen for convenience, and also because this investigation seeks to study relationships between variables rather than accurately estimating population values (Cozby, 2003). Thus, considering that the observation and information group contains the set of experiences and expressions that are intended to be achieved, this qualitative exploratory study included: 3 pairs of 
mother-infants diagnosed with reflux (Subjects 1, 2, 3) and 2 pairs of mother-infants diagnosed with colic (Subjects 4 and 5), aged between 20 and 30 years and whose children were between 0 and 1 year old (both sexes).

The mothers, at the time of the survey, had no previous diagnosis of psychiatric or psychopathological disorders (psychosis, mood disorders, among others). There was no race and/or color control to include the pair in the sample.

\section{Instruments}

Semi-directed interview. We sought to know more about the mother-infant relationship (care, routine, fears, ease, difficulties, among others), pregnancy, conjugality, aspects related to child development, the psychosomatic phenomenon (reflux/colic) presented by the infant, and how it affected the mother-infant dyad.

Thematic Apperception Test (TAT). We used the boards 1, 2, $7 \mathrm{MF}, 10,12 \mathrm{~F}, 16$ and $18 \mathrm{MF}$ of this thematic projective test. Regarding the choice of these slides, the correlation between the research objectives and the Thematic Norms (Murray, 1943/2005) of the referred boards was used as criterion: Board 1 - involves relationship with authority as well as the ego ideal; Board 2 addresses women's roles (motherhood vs. professional achievement and reason vs. emotion); Board 7MF - evokes the area of relationship with the mother figure - which can be seen as a model, support or obstacle to the satisfaction of one's own needs (Murray, 1943/2005); Board 10 - addresses conflicts of the couple; Board 12F - verifies mother-daughter relations, criticism or acceptance of the maternal model (Murray, 1943/2005); Board 16 verifies the overall projection of the subject; and Board $18 \mathrm{MF}$ - how the female figure is represented (aggressive behavior turned to help or support). The application was according to the instructions of the test's original manual, version that was most recently updated in Brazil in 2005 after the instrument passed the psychological test system of the Federal Council of Psychology.

Researchers who have been devoted to the careful study of clinical use and research of the Thematic Apperception Test (TAT), one of the instruments used to collect research data presented here, Scaduto and Barbieri (2013) highlight the importance of professionals and researchers to systematically conduct researches with the TAT in order to improve its use and to know its scope and limits. In 2014, Pasian, Okino, Freitas, Osorio and Loureiro published a book entitled Desafios para a prática ética da avaliação psicológica (Challenges for the Ethical Practice of Psychological Assessment) as a result of papers presented at the Congress of the Brazilian Rorschach Association and Projective Methods. This publication adds important contributions regarding the systematization of knowledge in the area, as well as allows reflections on the possibilities of application of projective instruments in the professional practice of Psychology, whether clinical, researches, in different contexts and with different populations. Section 2 of this publication is entirely devoted to investigations with thematic appperception instruments, among which 4 are research papers that used TAT in their methodological scope.
Naturalistic observation. This is defined as a method of observing people in their particular natural environment (field), which aims to collect information during certain tasks (Cozby, 2003). This naturalistic observation occurred during an infant's feeding moment, in which the dynamics of the mother-infant relationship were observed, that is, we considered the mother's handling when she took the baby in her lap, her affective investment in relation to the child, how she directed her care to her child (how this care was occuring) and how she took the infant's productions, namely, her reaction to the infant's manifestations.

\section{Procedure}

Data collection. To obtain the data from this survey, some mothers from the social environment were selected, a selection defined by Cozby (2003) as a convenience sample. The initial contact was made by telephone and the first meeting was scheduled, in which the information letter and the informed consent form for subsequent signature were was provided and read with the subject. Also in the first meeting, a semidirected interview was conducted, whose script was developed exclusively to meet the survey objectives, that is, to raise aspects related to the mother-infant dyad, child development, among others, as already presented in the sub-item "Instruments". TAT was applied in a second meeting. This sequence of collection procedures was repeated for each subject.

At the meeting for the application of TAT, the subject was asked to tell stories according to the boards presented and, if necessary, after each report, a survey was carried out to list elements that had not been clear or were missing from the story's structure. All instructions were given according to the test manual (Murray, 1943/2005). In the third meeting with the subject, the mother-infant relationship was observed, as previously described in detail in the sub-item "Instruments". It is worth mentioning that, as in the case of the semi-directed interview, an observation script was developed to meet the survey objectives.

Data analysis. The analysis procedure was quantitative and qualitative, since descriptive data were collected from the interview, whose mother-infant relationship and the motherinfant-other triad were explored. After tabulating the most similar aspects reported by the mothers in the interviews, the data obtained on each TAT board were partially analyzed. In this analysis the following items were identified (content analysis proposed by Murray (1943/2005), creator of the technique): Hero; Need; Environment; Relationship with others; Conflict; Anxiety; Defenses; Outcome; Imago.

In the naturalistic observation we perceived how the mother took the infant's productions, if the mother "understood" what the infant "said" and wanted, if it was being considered as a different subject and separate from her, what were the times intended for the child, how were the instrumental acquisitions expected for the child's development phase and how the mother took care of the baby and responded to the demands directed to her. At the end of these partial analyses, an integrative analysis of 
the items described above was performed in light of the psychoanalytical theoretical framework. Therefore, this integration consisted of a psychodynamic understanding of the mother-infant pairs studied.

\section{Ethical Considerations}

Firstly, the survey was approved by the Internal Research Ethics Committee, process CIEP No. T010/05/07. In this study there were remote possibilities of emotional reactions, due to the questions asked during the data collection process regarding the mother-infant dyad. In view of this, the aim was to ensure appropriate protection of the participants' rights and well-being.

The research objectives were explicit from the first contact and informed consent was used, which addressed "the purposes of the study, the risks associated with the procedures and right to refuse or discontinue participation in the study" (Cozby, 2003, p. 56). All data obtained that were related to the identity of subjects were kept absolutely confidential, as well as their privacy was respected.

\section{Results and Discussion}

Table1, Table 2 and Table 3 summarize the responses extracted from semi-directed interviews, data obtained by naturalistic observation and content analysis of TAT boards.

Some specificities of routine care, aspects of child development, and mother's position in the bonding with her baby were presented in Table 1. Compared to the data presented in Table 2, the position of the mother as the one who names the child's demands and is in a position to respond will be specially more prominent.

Table 1

Relevant Data on Interviews with Mothers of the Colic and Reflux Groups

\begin{tabular}{|c|c|c|c|c|c|}
\hline $\begin{array}{l}\text { Relevant data from } \\
\text { interviews }\end{array}$ & $\begin{array}{l}\text { Subject } 1 \\
\text { (Reflux) }\end{array}$ & $\begin{array}{l}\text { Subject } 2 \\
\text { (Reflux) }\end{array}$ & $\begin{array}{l}\text { Subject } 3 \\
\text { (Reflux) }\end{array}$ & $\begin{array}{l}\text { Subject } 4 \\
\text { (Colic) }\end{array}$ & $\begin{array}{l}\text { Subject } 5 \\
\text { (Colic) }\end{array}$ \\
\hline Infant's age & 9 months & 9 months & 4 months & 4 months & 11 months \\
\hline Pregnancy & $\begin{array}{l}\text { Anxious and fear of } \\
\text { losing the child }\end{array}$ & $\begin{array}{l}\text { She had placental } \\
\text { detachment }\end{array}$ & $\begin{array}{l}\text { Quiet, only in late } \\
\text { pregnancy she had } \\
\text { heartburn }\end{array}$ & $\begin{array}{l}\text { She was happy } \\
\text { and accepted the } \\
\text { situation better than } \\
\text { her husband }\end{array}$ & $\begin{array}{l}\text { She had a urinary } \\
\text { tract infection, } \\
\text { swelled up and had } \\
\text { a lot of pain. }\end{array}$ \\
\hline $\begin{array}{l}\text { Reaction after the } \\
\text { child's birth }\end{array}$ & $\begin{array}{l}\text { She was very } \\
\text { happy, but afraid of } \\
\text { throwing the child } \\
\text { out of the window }\end{array}$ & $\begin{array}{l}\text { When she was } \\
\text { breastfeeding, she } \\
\text { thought it would be } \\
\text { for life. }\end{array}$ & $\begin{array}{l}\text { She was scared } \\
\text { because the baby } \\
\text { was born very hairy }\end{array}$ & $\begin{array}{l}\text { The baby has } \\
\text { become the focus, } \\
\text { she thinks of } \\
\text { it before doing } \\
\text { anything }\end{array}$ & $\begin{array}{l}\text { She was very happy } \\
\text { and insecure, had } \\
\text { no nurse at home to } \\
\text { help her }\end{array}$ \\
\hline $\begin{array}{l}\text { Breastfeeding time - } \\
\text { Age of Weaning }\end{array}$ & 45 days & 8 months & $\begin{array}{l}1 \text { and a half months, } \\
\text { because the milk } \\
\text { has become solid. }\end{array}$ & Still breastfeeding & $\begin{array}{l}8 \text { and a half months, } \\
\text { with pharyngitis it } \\
\text { lost interest. }\end{array}$ \\
\hline $\begin{array}{l}\text { Colic or reflux } \\
\text { episode }\end{array}$ & $\begin{array}{l}\text { At } 12 \text { days, at the } \\
\text { end of breastfeeding } \\
\text { the baby had the } \\
\text { face full of milk and } \\
\text { all purple }\end{array}$ & $\begin{array}{l}\text { At } 20 \text { days the } \\
\text { baby vomited after } \\
\text { breastfeeding and } \\
\text { went to the hospital }\end{array}$ & $\begin{array}{l}\text { In all feedings the } \\
\text { baby would burp } \\
\text { and throw up }\end{array}$ & $\begin{array}{l}\text { It has a sudden cry, } \\
\text { legs well stretched, } \\
\text { gets hard and } \\
\text { nothing comforts it }\end{array}$ & $\begin{array}{l}\text { At one and a half } \\
\text { months the baby } \\
\text { cried so much } \\
\text { because of colic } \\
\text { that it lost its breath }\end{array}$ \\
\hline $\begin{array}{l}\text { Meaning of the } \\
\text { symptom for the } \\
\text { mother }\end{array}$ & She does not know & $\begin{array}{l}\text { It did not change } \\
\text { anything }\end{array}$ & $\begin{array}{l}\text { She does not know } \\
\text { what it means }\end{array}$ & $\begin{array}{l}\text { It means something } \\
\text { natural, but it brings } \\
\text { her closer to the } \\
\text { baby }\end{array}$ & $\begin{array}{l}\text { She was very } \\
\text { worried and saw } \\
\text { that the baby } \\
\text { needed her badly. }\end{array}$ \\
\hline $\begin{array}{l}\text { Feelings of mothers } \\
\text { in the face of crises } \\
\text { of colic or reflux }\end{array}$ & $\begin{array}{l}\text { She felt bad, } \\
\text { thought the crises } \\
\text { were due to her } \\
\text { anxiety during } \\
\text { pregnancy and } \\
\text { breastfeeding }\end{array}$ & $\begin{array}{l}\text { I was upset, I } \\
\text { thought it hurt } \\
\text { and that it was } \\
\text { uncomfortable for } \\
\text { the baby }\end{array}$ & $\begin{array}{l}\text { She felt desperate } \\
\text { and rushed to clean } \\
\text { the baby so it would } \\
\text { not choke }\end{array}$ & $\begin{array}{l}\text { She felt useless, } \\
\text { having to wait for } \\
\text { the medicine to take } \\
\text { effect }\end{array}$ & $\begin{array}{l}\text { She was very } \\
\text { worried, it generated } \\
\text { a trauma. She } \\
\text { thought she passed } \\
\text { the insecurity to } \\
\text { the baby }\end{array}$ \\
\hline
\end{tabular}


Table 2

Mother-Infant Pair Comparison from Naturalistic Observation

\begin{tabular}{|c|c|c|c|c|c|}
\hline & Subject 1 & Subject 2 & Subject 3 & Subject 4 & Subject 5 \\
\hline Symptom & Reflux & Reflux & Reflux & Colic & Colic \\
\hline Age (baby) & 9 months & 9 months & 4 months & 4 months & 11 months \\
\hline $\begin{array}{l}\text { 1. Mother regarding } \\
\text { infant's productions }\end{array}$ & $\begin{array}{l}\text { She immediately } \\
\text { meets baby's needs }\end{array}$ & $\begin{array}{l}\text { She immediately } \\
\text { meets baby's needs }\end{array}$ & $\begin{array}{l}\text { She immediately } \\
\text { meets baby's needs }\end{array}$ & $\begin{array}{l}\text { She immediately } \\
\text { meets baby's needs }\end{array}$ & $\begin{array}{l}\text { She immediately } \\
\text { meets baby's needs }\end{array}$ \\
\hline $\begin{array}{l}\text { 2. Mother regarding } \\
\text { infant's reactions } \\
\text { and manifestations }\end{array}$ & $\begin{array}{l}\text { Baby seen as } \\
\text { different and } \\
\text { separate from } \\
\text { mother }\end{array}$ & $\begin{array}{l}\text { Baby has room } \\
\text { to explore } \\
\text { environment, } \\
\text { seen as different } \\
\text { and separate from } \\
\text { mother }\end{array}$ & $\begin{array}{l}\text { Baby seen as } \\
\text { different and } \\
\text { separate from } \\
\text { mother, although } \\
\text { dependent on her }\end{array}$ & $\begin{array}{l}\text { Fully integrated, } \\
\text { mother-dependent } \\
\text { baby }\end{array}$ & $\begin{array}{l}\text { Baby seen as } \\
\text { different and } \\
\text { separate from } \\
\text { mother }\end{array}$ \\
\hline $\begin{array}{l}\text { 3. Schedules for the } \\
\text { baby }\end{array}$ & $\begin{array}{l}\text { Mother does not } \\
\text { stay long with baby, } \\
\text { has time for herself }\end{array}$ & $\begin{array}{l}\text { Mother respects } \\
\text { baby's schedule }\end{array}$ & $\begin{array}{l}\text { Mother stays with } \\
\text { the baby, but also } \\
\text { leaves it at the } \\
\text { grandmother's } \\
\text { house }\end{array}$ & $\begin{array}{l}\text { Baby has a daily } \\
\text { routine with mother. } \\
\text { She often stops } \\
\text { eating to take care } \\
\text { of it }\end{array}$ & $\begin{array}{l}\text { Mother is } \\
\text { responsible for the } \\
\text { baby full time. The } \\
\text { father helps }\end{array}$ \\
\hline $\begin{array}{l}\text { 4. Instrumental } \\
\text { Acquisitions within } \\
\text { Expected Time }\end{array}$ & $\begin{array}{l}\text { Baby presents } \\
\text { expected } \\
\text { acquisitions for } \\
\text { its age }\end{array}$ & $\begin{array}{l}\text { Baby presents } \\
\text { expected } \\
\text { acquisitions for its } \\
\text { age }\end{array}$ & $\begin{array}{l}\text { Baby presents } \\
\text { expected } \\
\text { acquisitions for its } \\
\text { age }\end{array}$ & $\begin{array}{l}\text { Baby presents } \\
\text { expected } \\
\text { acquisitions for its } \\
\text { age }\end{array}$ & $\begin{array}{l}\text { Baby presents } \\
\text { expected } \\
\text { acquisitions for its } \\
\text { age }\end{array}$ \\
\hline $\begin{array}{l}\text { 5. Mother regarding } \\
\text { care for the infant }\end{array}$ & $\begin{array}{l}\text { Mother is } \\
\text { responsible for the } \\
\text { care of the baby. } \\
\text { The father helps }\end{array}$ & $\begin{array}{l}\text { Mother is } \\
\text { responsible for } \\
\text { the care, but needs } \\
\text { the help of the } \\
\text { grandmother, since } \\
\text { the father does } \\
\text { little help }\end{array}$ & $\begin{array}{l}\text { Mother is partly } \\
\text { responsible for the } \\
\text { care of the baby. } \\
\text { The maternal } \\
\text { grandmother helps } \\
\text { and the father } \\
\text { helps little }\end{array}$ & $\begin{array}{l}\text { Mother is } \\
\text { responsible for the } \\
\text { care of the baby. } \\
\text { Father helps little }\end{array}$ & $\begin{array}{l}\text { Mother is } \\
\text { responsible for the } \\
\text { care of the baby. } \\
\text { The father helps }\end{array}$ \\
\hline
\end{tabular}

Table 3

Comparison between Mother-Subject Responses to TAT Boards

\begin{tabular}{|c|c|c|c|c|c|}
\hline \multicolumn{6}{|c|}{ Relevant Data On Tat Boards } \\
\hline Items analyzed & $\begin{array}{l}\text { S-1 } \\
\text { (Reflux) }\end{array}$ & $\begin{array}{l}\text { S } 2 \\
\text { (Reflux) }\end{array}$ & $\begin{array}{l}\text { S.3 } \\
\text { (Reflux) }\end{array}$ & $\begin{array}{l}\mathrm{S}-4 \\
\text { (Colic) }\end{array}$ & $\begin{array}{l}\text { S.5 } \\
\text { (Colic) }\end{array}$ \\
\hline Need & $\begin{array}{l}\text { Affiliation and } \\
\text { Security }\end{array}$ & $\begin{array}{l}\text { Affiliation, Security } \\
\text { and Achievement }\end{array}$ & $\begin{array}{l}\text { Affiliation and } \\
\text { Security }\end{array}$ & $\begin{array}{l}\text { Affiliation, Fun and } \\
\text { Accreditation }\end{array}$ & $\begin{array}{l}\text { Affiliation and } \\
\text { Achievement }\end{array}$ \\
\hline Environment & $\begin{array}{l}\text { Affection and } \\
\text { Affiliation }\end{array}$ & $\begin{array}{l}\text { Affection and } \\
\text { Affiliation }\end{array}$ & $\begin{array}{l}\text { Affection and } \\
\text { Affiliation }\end{array}$ & $\begin{array}{l}\text { Affection, } \\
\text { Affiliation and } \\
\text { Friendships }\end{array}$ & $\begin{array}{l}\text { Affection, } \\
\text { Affiliation } \\
\text { and Need for } \\
\text { Tenderness }\end{array}$ \\
\hline Conflict & $\begin{array}{l}\text { Autonomy vs. } \\
\text { Dependence }\end{array}$ & $\begin{array}{l}\text { Autonomy vs. } \\
\text { Dependence }\end{array}$ & $\begin{array}{l}\text { Capacity vs. } \\
\text { Incapacity }\end{array}$ & $\begin{array}{l}\text { Success } \\
\text { vs. } \\
\text { Failure }\end{array}$ & $\begin{array}{l}\text { Success } \\
\text { vs. } \\
\text { Failure }\end{array}$ \\
\hline Anxiety & $\begin{array}{l}\text { Self Image, } \\
\text { Self-Ability and } \\
\text { Impotence }\end{array}$ & $\begin{array}{l}\text { Self Image, } \\
\text { Self-Ability and } \\
\text { Impotence }\end{array}$ & $\begin{array}{l}\text { Self Image, } \\
\text { Self-Ability and } \\
\text { Impotence }\end{array}$ & $\begin{array}{l}\text { Self-Image and } \\
\text { Self-Ability }\end{array}$ & $\begin{array}{l}\text { Self-image, Self- } \\
\text { ability }\end{array}$ \\
\hline Outcome & Tailored solution & Tailored solution & No solution & Tailored solution & Tailored solution \\
\hline
\end{tabular}


As it can be seen in Table 2, some information provided verbally and consciously in the interviews (Table 1) sometimes corroborates the data obtained by naturalistic observation and sometimes leaves gaps and contradictions between manifest and latent discourses. Given this, therelevance of the researcher to go to the natural environment of the subjects observed becomes evident.

As it can be seen in Table 1, Table 2 and Table 3, the similarities found in the group of mothers with infants with reflux were related to weaning and to the need for third-party support regarding care for the infant.

According to Pincus \& Dare (1981) the mother must include the father in the care for the infant, because when she allows greater participation of the father, her isolation will be less frequent, which will allow her to be more emotionally and physically engaged to meet the child's demands. (Rapoport \& Piccinini, 2011). However, in subjects 2 and 3, who most assisted in the care was the maternal grandmother and the discourse of these mothers was precisely that the father helped little (Table 2 and Table 3).

According to the data in Table 3, all subjects in the reflux group (subjects 1, 2 and 3) presented anxiety regarding their own capacity, self-image and feelings of helplessness regarding the care related to the infant and reflux crises. According to their reports, they felt guilty, helpless, and desperate. In addition, maternal ambivalence (love and anger) towards the baby was observed. During pregnancy, subjects 1 and 2 showed fear of losing the baby and placental detachment, respectively. It is noteworthy that subject 1 , despite not having a "real" problem, faced with the fear of losing the baby, felt anxious and nervous.

Regarding weaning, a moment highlighted by the literature as possibly involved in the onset of psychofunctional symptoms in the baby, subjects 1 and 3 performed it early (Table 1), and subject 2 did it after a long period. Thus, according to Costa et al. (2004), reflux episodes may be due to this early weaning.

The similarities found in mother-infant pairs with colic (subjects 4 and 5) were related to anxiety regarding the care of the infant, encompassing their own capacity and self-image. It was also found that both subjects (4 and 5) needed support (affiliation), since their partners presented, according to their reports, jealousy and deprivation after the child's birth. Although the partner presents this behavior, in subject 5, there was his support and assistance in the care of the infant.

The subjects are anxious about their performance in maternal care, which according to Saavedra et al. (2003) may be a symptom derived from specificities of the mother-infant dyad and/or family context. Cristoffel et al. (2013) reiterate that mothers dealing with their child's colic situation show reports of tension, feelings of anxiety, irritation, insecurity, tiredness and depression. Thus, parents may be beset by inexperience, anxiety, depression or even feelings of anger, which may arise defensively in the face of feelings of insecurity.

Therefore, faced with these affections the subjects presented several conflicts, which could be observed in the content of the stories elaborated in front of the TAT boards. For these conflicts, the solutions presented were not always adapted (socially accepted solution, obtained on their own and in an autonomous way) or elaborated, which points to an egoic fragility compatible with the context they were experiencing: that of newborn motherhood.

In both mother-infant pairs, feelings in the face of colic crises seemed to be linked to impotence, concern and guilt, which according to the literature may overdetermine the onset of colic symptoms.

The similarities found between the group of mothers of colicky infants and mothers of infants with reflux refer to the presence of anxiety regarding child care and the need for affiliation. From the material collected, including interviews, it is thought that anxiety arises, possibly, as a result of insecurity in the face of the difficult task of caring for the baby, which becomes even more arid when the child actually has some difficulty, as crises of colic and reflux. Thus, it is assumed that these are sufficient reasons for narcissistic aftershocks that disrupt the self-image of mothers who begin to question their own ability to face the task, a question that often affects the quality of their mothering, which includes the holding capacity. This holding with desiring availability becomes threatened in those cases in which the most pressing affections for the child anxiety and ambivalence.

Still considering what was presented as similarity, all subjects reported that the family dynamics changed after the child's birth, generating the need for some adjustments. These adjustments varied from subject to subject, and were characterized by, from changes in the hours of routine activities to the distance of the partner (jealousy, deprivation). According to Pincus \& Dare (1981), difficulties in the couple's relationship may be related to the denial of a third person being part of this relationship. This behavior is usually unconscious, generated by the husband's fear of losing the exclusivity of his wife's love.

It is noteworthy that no relationship is exempt from mismatches, since when conceiving a child there are several transformations in women's lives, but it is known that when mismatches occur they seem to be the source of psychosomatic disorganization, which babies are vulnerable to because of their psychic apparatus immaturity, of the sovereignty of their organisms, and of being marked as human subjects by the drive.

Finally, it is considered that colic symptoms may be related to the quality of the interaction between mother and infant, taking into account that these mothers were anxious and insecure when managing their children, normative conflicts generated by inexperience, anxiety and lack of support. In the words of Edelstein (2000), "the symptom shows us the tendency of an infant to respond as it can, through the body pathway, to the inadequate emotional circumstances of the environment in which it lives" (p. 74).

The mothers of babies with reflux were found to relate regurgitation as the result of their nervousness and anxiety during pregnancy. These attitudes of the subject may indicate the presence of ambivalence (love and anger) in the relationship with their child, and the fear reported by subject 1 that something might happen to the baby probably unconsciously corresponds to her own desire to lose it, perhaps as an alternative to ease the anguish at the task of mothering. It is noteworthy that, with regard to ambivalence, 
there are also the conflicts between unconscious desire and conscious will. In this sense Barros \& Herzberg (2012) point out that the father may be the one who offers as a substitute for the mother, presenting the child with another drive offer/ demand, which can be very important so that the infant can be better protected from maternal ambivalence.

The mothers of infants with reflux, when asked about the meaning of the symptom, replied that they did not know what it meant. These results are in line with what Edelstein (2000) and Scalco \& Donelli (2014) pointed out about the expression of suffering in infants through the body in those cases in which the relationship with the mother is not providing sufficiently good psychic support, that is, not operating the excitement stop function, as described by Ranña (2015), essential for the infant's healthy development. It was possible to notice the difficulty of naming the discomfort of babies, and this is not without effect on the way the maternal function operates in relation to the child, since these mothers do not seem to be allowed to know about what was happening to their children, leaving it to Medicine to name their children's malaise as reflux.

When highlighting as research data that the mothers of colicky babies had anxiety regarding the care of their infant, which may have contributed to the onset of this symptom, it brings a contribution to the psychosomatic area since the results of this qualitative exploratory investigation corroborate the study by Cristoffel et al. (2013), which points out that the emotional origin of colic is more common than the gastrointestinal. The subjects with infants with reflux, on the other hand, showed a relationship marked by maternal ambivalence, which appears especially in the care given to the baby: "I was afraid of throwing it out the bathroom window, afraid that during the shower I would throw water on him on purpose (sic) "and thought "now it is for the rest of my life, is it really mine?"” (sic).

This survey highlighted the influence of the environment that, when supportive, the mothers showed to feel better able to take care of their child, but when there was stress, demands and lack of company/partnership, these mothers became more anxious and less self-confident in the exercise of sufficiently good mothering, not offering sufficiently good psychic support.

Regarding the use of TAT, it is considered an instrument of fundamental importance; once exposed to the boards, the subject - without realizing it - identifies with the character and communicates their perceptive experience through a complete story. In this way, it is possible to know which situations and relationships suggest desires, fears, and difficulties to the subject, as well as essential needs and pressures in the underlying dynamics of their personality (Murray, 1943/2005).

Finally, considering the results of this survey, it is possible to build a material that contributes preliminarily to the scope of psychological science, as well as it is informative for society, especially for mothers. It is believed that this investigation has scientific relevance that may contribute to further studies in the psychology field, since there is a shortage of published material exploring the symptoms of colic and reflux in the first year of life and their repercussions on the mother-infant dyad.

However, it draws attention to some limitations of this study highlighting the importance of addressing the gaps left in future researches in the area of qualitative research in psychology, such as the deepening of the aspects inherent in these mothers' self-image, the relationship between symptoms in infants, and maternal sexuality, and the repercussions on the family dynamics with the child's birth. These themes were not addressed in this study precisely because they arose from their realization.

\section{References}

Barros, I. P. M., \& Herzberg, E. (2012). A maternidade e sua essência problemática na constituição subjetiva: $\mathrm{O}$ que escapa e o que se pode prevenir na primeira infância [Maternity and its problematic essence in the subjective constitution: What escapes 'and what can be prevented in early childhood]. In M. C. M. Kupfer, L. M. F. Bernardino, \& R. M. M. Mariotto (Orgs.), Psicanálise e ações de prevenção na primeira infância [Psychoanalysis and prevention actions in early childhood] (pp. 259-286). São Paulo, SP: Escuta/FAPESP.

Costa, A. J. F., Silva, G. A., Gouveia, P. A. C., \& Pereira Filho, E. M. (2004). Prevalence of pathologic gastroesophageal reflux in regurgitant infants. Jornal de Pediatria, 80(4), 291-295. doi:10.1590/S0021-75572004000500008

Cozby, P. C. (2003). Métodos de pesquisa em ciências do comportamento [Behavioral science research methods] (P. I. C. Gomide \& E. Otta, Trans.). São Paulo, SP: Vozes.

Cristoffel, M. M., Silva, L. R., Silva, L. R., Ferreira, A. C. G. V., \& Macedo, E. C. (2013). Infant colic: Descriptive study of maternal care practices for pain relief. Revista Enfermagem UFPE On Line, 7(10), 5876-5872. doi:10.5205/reuol.4377-36619-1-ED.0710201306

Edelstein, T. M. (2000). A interação mãe-bebê: Os sintomas psicossomáticos e o pediatra [The interaction mother-baby: The psychosomatics symptoms and the pediatrician]. Pediatria Moderna, 36(1/2), 70-74.

Murray, H. A. (2005). Teste de apercepção temática [Thematic apperception test] (M. C. V. Silva, Adap., 3rd ed.). São Paulo, SP: Casa do Psicólogo. (Original work published 1943).

Oba, J., \& Falcão, M. C. (2014). Resposta clínica favorável em um dia dos distúrbios gastrintestinais leves após troca de fórmula de rotina comum para fórmula com proteína parcialmente hidrolisada e com baixos teores de lactose [Clinical response to 2 commonly used switch formulas occurs within 1 day]. Pediatria Moderna, 50(7), 360-362. 
Pasian, S. R., Okino, E.T. K., Freitas, F. R., Osório, F. L., \& Loureiro, S. R. (Orgs.). (2014). Desafios para a prática ética da avaliação psicológica: Congresso da Associação Brasileira de Rorschach e Métodos Projetivos [Challenges for the ethical practice of psychological assessment: Congress of the Brazilian Rorschach Association and Projective Methods]. Ribeirão Preto, SP: ASBRo. Retrieved from https://www.asbro.org.br/ arquivos/Desafios_para_a_pratica_etica_da_Avaliacao_ Psicologica_Livro_CD_VII_Cong_ASBRo_2014.pdf

Peruchi, R. C., Donelli, T. M. S., \& Marin, A. H. (2016). Ajustamento conjugal, relação mãe-bebê e sintomas psicofuncionas no primeiro ano de vida [Marital adjustment, mother-infant relationship and psychofunctional symptoms in the firstyearoflife]. Quaderns de Psicologia, 18(3), 55-67. doi:10.5565/rev/qpsicologia.1363

Pincus, L. E., \& Dare, C. (1981). Psicodinâmica da família [Secrets in the family] (C. Rotenberg \& S. Kleinke, Trans.]. Porto Alegre, RS: Artes Médicas.

Puccini, F. R. S., \& Berretin-Felix, G. B. (2015). Gastroesophageal reflux and swallowing in newborns and infants: Integrative review of literature. Revista CEFAC, 17(5), 1664-1673. doi:10.1590/1982-021620151753615

Ranña, W. (2015). Psicossomática e o infantil: Uma abordagem através da pulsão e da relação objetal [Psychosomatic and infantile: An approach through the drive and object relation]. In F. C. Ferraz \& R. M. Volich (Orgs.), Psicossoma I: Psicanálise e psicossomática [Psychosoma I: Psychoanalysis and psychosomatic] (pp. 105-129). São Paulo, SP: Casa do Psicólogo.

Rapoport, A., \& Piccinini, C. A. (2006). Apoio social e experiência da maternidade [Social support and the experience of maternity]. Revista Brasileira de Crescimento e Desenvolvimento Humano, 16(1), 85-96. Retrieved from http:// pepsic.bvsalud.org/scielo.php?script=sci_ arttext\&pid=S0104-12822006000100009

Rapoport, A., \& Piccinini, C. A. (2011). Maternidade e situações estressantes no primeiro ano de vida do bebê [Motherhood and stressful situations in the first year of the baby's life]. Psico-USF, 16(2), 215-225. doi:10.1590/ S1413-82712011000200010

Ravanelli, A. F., Côrtes, M. A., \& Valentim, F. C. V. (2012). Concepções maternas acerca da presença de refluxo gastroesofágico em lactentes de 0 a 24 meses [Maternal conceptions about the presence of gastroesophageal reflux in infants from 0 to 24 months]. Interdisciplinar: Revista Eletrônica da Univar, 1(8), 74-79.

Saavedra, M. A., Costa, J. S. D., Garcias, G., Horta, B. L., Tomasi, E., \& Mendonça, R. (2003). Incidência de cólica no lactente e fatores associados: Um estudo de coorte [Infantile colic incidence and associated risk factors: A cohort study]. Jornal de Pediatria, 79(2), 115-122. doi:10.1590/S0021-75572003000200005
Scalco, M. O., \& Donelli, T. M. S. (2014). Os sintomas psicofuncionais e a relação mãe-bebês gêmeos aos nove meses de idade [Symptoms psychofunctional and the mother-twin babies at nine months of age]. Temas em Psicologia, 22(1), 55-66. doi:10.9788/TP2014.1-05

Scaduto, A. A., \& Barbieri, V. (2013). Em defesa do TAT: Uma revisão crítica das pesquisas sobre o teste no Brasil [In defense of the TAT: A critical review of the test research in Brazil]. Avaliação Psicológica, 12(3), 299-305. Retrieved from http://pepsic.bvsalud.org/scielo.php?script=sci arttext\&pid=S1677-04712013000300004.

Vendruscolo, J. F., Bolzan, G. M., Crestani, A. H., Souza, A. P. R., \& Moraes, A. B. (2012). A relação entre o aleitamento, transição alimentar e os indicadores de risco para o desenvolvimento infantil [The relationship between breastfeeding, food transition and risk indicators for child development]. Distúrbios da Comunicação, 24(1), 4152. Retrieved from http://revistas.pucsp.br/index.php/dic/ article/view/9704

Winnicott, D. W. (1982). A criança e o seu mundo [The child, the family, and the outside world] (A. Cabral, Trans., 6th ed.). Rio de Janeiro, RJ: Guanabara Koogan. (Original work published 1965)

Winnicott, D. W. (2000). Da pediatria à psicanálise: Obras escolhidas [Through pediatrics to psychoanalysis: Collected papers] (D. Bogomoletz, Trans.) Rio de Janeiro, RJ: Imago. (Original work published 1958)

Deborah Juliana dos Santos Zacara is a Psychologist graduated from Universidade Presbiteriana Mackenzie, São Paulo-SP, Brazil.

Izabella Paiva Monteiro de Barros is a PhD Professor of the Universidade Federal do Pará, Belém-PA, Brazil.

\section{Authors' Contribution:}

All authors made substantial contributions to the conception and design of this study, to data analysis and interpretation, and to the manuscript revision and approval of the final version. All the authors assume public responsibility for the content of the manuscript.

Received: Mar. 23, 2017

1st Revision: Jun. 09, 2017

Approved: Apr. 02, 2018

How to cite this article

Zacara, D. J. S., \& Barros, I. P. M. (2020). Psychodynamic study about reflux and colic's during the first year of life. Paidéia (Ribeirão Preto), 30, e3005. doi: http://dx.doi.org/10.1590/1982-4327e3005 